\title{
Een sociologische reflectie op het veldexperiment Food in Motion
}

\author{
Sigrid C. O. Wertheim-Heck
}

(C) The Author(s) 2020

\begin{abstract}
Samenvatting Onderzoekers van de Universiteit Utrecht hebben een interessant veldexperiment uitgevoerd: het aanbieden van een gezonde snack op station Utrecht Centraal. Hoewel de reizigers aangaven een groter aanbod van gezonde snacks te appreciëren, vielen de verkopen tegen. Hoe kan dit worden verklaard? Dit artikel biedt een reflectie vanuit de theorie van sociale praktijken. Belangrijke aandachtspunten hierin zijn routinematigheid en gewoonte. Aan de hand van de variabelen locatie, verkooppunt, assortiment en product, wordt ingezoomd op de praktijk - wat zijn de kenmerkende elementen van snacken op het station - en uitgezoomd - hoe is de praktijk van snacken op het station verbonden met andere (dagelijkse) activiteiten van de reizigers? De reflectie demonstreert hoe het experiment, gebaseerd op een causaliteit tussen aanbod en vraag, voor de reizigers een complexe verandering in hun gedragspatronen betrof, met meerdere breuken in bestaande routines: een nieuw product, via een nieuw verkooppunt, op een nieuwe plek en daarmee op een ander moment tijdens het treinreizen. Wanneer voedselconsumptie wordt geïsoleerd van het scala aan vaak (gecombineerde) gedragspatronen waarvan het onderdeel uitmaakt, dan bestaat het risico dat niet alle relevante aspecten worden meegenomen in het ontwerp van een interventie.
\end{abstract}

Trefwoorden theorie van sociale praktijken . routines · gewoonten · gedragspatronen · dagelijks leven

\section{S. C. O. Wertheim-Heck ( $ه)$}

Milieubeleid, Wageningen Universiteit, Wageningen, Nederland

Voedsel en Gezond Leven, Aeres Hogeschool Almere, Almere, Nederland

sigrid.wertheim-heck@wur.nl

\section{A sociological reflection on the field experiment Food in Motion}

Abstract Why do we prefer unhealthy snacks? What is the role of the food environment? To investigate this, researchers from Utrecht University conducted the Food in Motion field experiment: offering a healthy snack in the obesogenic food environment of Utrecht central station. Although travellers stated that they 'appreciate a larger selection of healthy snacks', sales were disappointing. How can this be explained? This article offers a social practice theories informed reflection. Important points of attention herein are routines and habits. Based on the variables location, point of sale, assortment and product, the article zooms in on the characteristic elements of snacking at the station and assesses - zooming out - on how the practice of snacking at the station is connected to other (daily) activities of travellers. The reflection demonstrates how the experiment, based on a causality between supply and demand, involved a complex change in behavioural patterns with multiple breaks in existing routines: a new product, via a new sales outlet, at a new location and therewith at a new moment within the train travel practice. When food consumption is isolated from the wider range of interconnected behaviour patterns, it risks excluding relevant aspects in the design of an intervention.

Keywords social practice theory $\cdot$ routines $\cdot$ habits · behavioural patterns · everyday life

\section{Inleiding}

Waarom (ver)kiezen we ongezonde snacks? Wat is daarbij de rol van de voedselomgeving? Om dit te onderzoeken hebben onderzoekers van de Universiteit Utrecht een veldexperiment uitgevoerd, Food in $\mathrm{Mo}$ - 
tion. Het experiment bestond uit een interventie in de obesogene voedselomgeving van een treinstation, in dit geval de snackhotspot station Utrecht Centraal. Onder de noemer 'de juiste snack op de juiste plaats' is een gezond en smakelijk tussendoortje ontwikkeld en aangeboden als alternatief voor het ruime aanbod aan calorierijke, te vette, te zoete en te zoute snacks. Wars van belerende voorlichtingscampagnes en opgelegde keuzen waren er twee centrale pijlers in het ontwerp van het experiment: het product - 'gezonde snacks die er lekker uitzien' - en de plaats - 'gemakkelijk te verkrijgen'. Het experiment was gericht op het meten van verandering in het voedselconsumptiegedrag. De aanname was dat de gemakkelijke toegankelijkheid van een aantrekkelijk, maar gezond tussendoortje kan bijdragen aan een hogere consumptie van die snack. Daarmee berustte het experiment op een veronderstelde causaliteit tussen voedselomgeving en gedrag: 'het idee dat het aanbod de vraag schept'. De werkelijkheid bleek echter weerbarstiger. De keuze voor het treinstation voor de interventie was goed gemotiveerd en het ontwikkelde tussendoortje leek ook aan de voorwaarden van een passend en smakelijk alternatief te beantwoorden: gezonde receptuur, gewaardeerd door consumenten. Toch viel de verkoop tegen. Hoe kan dit worden verklaard?

\section{Theoretische invalshoek - voedselpraktijken}

Dit artikel biedt een reflectie vanuit de theorie van sociale praktijken, waarin niet het individu en diens individuele voedselconsumptiegedrag centraal staan, maar de nadruk ligt op voedselconsumptiepraktijken [1-3]. Deze theorie betreft de manier waarop sociale wezens, met hun uiteenlopende leefstijlen, motieven en intenties, de wereld waarin ze leven maken en transformeren. Centraal staat onderzoek naar de wederzijdse en dynamische relatie tussen sociale structuur en menselijk handelen [4]. Bij het Utrechtse experiment betekent dit concreet dat de voedselconsumptiegedragingen van treinreizigers op het station worden onderzocht als resultante van enerzijds de voedselomgeving en anderzijds de bredere beweegredenen en activiteiten in het dagelijks leven van de reizigers. Belangrijke aandachtspunten hierin zijn routinematigheid en gewoonte, de minder bewuste en doordachte gedragspatronen van alledag. De resultaten van het Food in Motion-experiment benadrukken dat consumenten zich niet eenvoudig laten sturen in hun voedselconsumptiegedrag. Hoewel de reizigers aangaven een groter aanbod van gezonde snacks te appreciëren, is het aannemelijk dat ze zich grotendeels op de automatische piloot gedragen. Vergelijkbare discrepanties tussen intenties en daadwerkelijk handelen, tussen waarderen en consumeren zijn aantoonbaar herleid tot routinematige gewoonten [5]. Gedragsverandering blijkt een uitdaging en gaat verder dan variaties in de marketingmix met product, prijs, plaats en promotie als determinanten van individueel keuzegedrag.

\section{Reflectie vanuit voedselpraktijken}

De onderzoekers beschrijven hun veldexperiment als volgt: '... door een nieuwe gezonde en aantrekkelijke snack aan te bieden vanuit een kleine mobiele food truck, waardoor we de mogelijkheid hadden om nog dichter bij de specifieke plek te komen waar de ongezonde keuze meestal plaatsvindt'. Met de theorie van sociale praktijken als uitgangspunt gaan we verder in op de variabelen locatie, verkooppunt, assortiment en product. Daarbij hanteren we twee perspectieven, enerzijds inzoomen op de praktijk - wat zijn de kenmerkende elementen van snacken op het station -, en anderzijds uitzoomen - hoe is de praktijk van snacken op het station verbonden met andere (dagelijkse) activiteiten van de reizigers [6]?

\section{Locatie}

Het experiment is uitgevoerd op het plein voor de stationshal, het Jaarbeursplein. De zinsnede 'nog dichter bij de specifieke plek' lijkt belangrijk in het zoeken naar verklaringen voor het achterblijven van de verkoopcijfers. De 'echte' snackhotspot is de stationshal. De interventie vond plaats in de directe omgeving van de stationshal, maar niet in de stationshal zelf. Wanneer het merendeel van het voedsel in de stationshal wordt geconsumeerd, dan is het stationsplein al een minder geëigende locatie. Behalve het feit dat het net buiten de hotspot valt zijn ook de condities voor voedselconsumptie daar anders. De stationshal is overdekt, terwijl het stationsplein zich in de openlucht bevindt, waardoor bijvoorbeeld weersomstandigheden een rol kunnen spelen. Naast locatiespecifieke omstandigheden heeft de keuze voor de 'plaats' ook andere implicaties. Door de snack buiten de stationshal aan te bieden, wordt deze niet alleen op een andere plek aangeboden, maar ook op een ander moment binnen de bestaande gedragspatronen van het treinreizen en forenzen. In het experiment 'isoleren' de onderzoekers het consumeren van voedsel van de bredere praktijken rondom het treinreizen. Op het station is de praktijk van de voedselconsumptie direct verbonden met de praktijk van het treinreizen. Die is gebonden aan dienstregelingen, die al dan niet verstoord kunnen zijn. Het halen van de trein of het wachten erop zijn van invloed op de consumptie. Zo staan reizigers zich bijvoorbeeld pas tijd toe om te snacken wanneer ze weten dat ze de trein halen, wat ze pas weten in de stationshal. Met andere woorden, de locatie bepaalt niet alleen de plaats, maar ook de tijd. 


\section{Verkooppunt}

Dit leidt tot de volgende vraag: wat als de food truck in de stationshal was geplaatst? Binnen routinematig gedrag zou het moment van aankoop dan niet hoeven te veranderen. Een nieuw, additioneel verkooppunt veronderstelt echter een bewuste keuze voor een ander aankooppunt dan treinreizigers gewoon zijn. In dit kader zijn de gedragspatronen van treinreizigers binnen het station relevant. Hoe spenderen verschillende groepen reizigers hun tijd en hoe bewegen ze zich binnen de stationshal? Zo wordt voedselconsumptie niet louter en alleen gedreven door trek in voedsel, maar heeft het bijvoorbeeld ook te maken met 'tijdverdrijf'. Enerzijds zou tijdverdrijf kunnen leiden tot nieuwsgierigheid in een nieuw verkooppunt en zou de plaatsing van de food truck in het station tot een hogere verkoop kunnen leiden dan op het stationsplein. De onderzoekers hebben in hun experiment onder meer gevarieerd met het element 'aspiratie' door een lange rij voor de food truck te plaatsen. Het effect bleek verwaarloosbaar. Wellicht dat binnen de stationshal een ander effect zou zijn gemeten. De keuze voor verkoop via een food truck is discutabel. Het experiment richt zich nadrukkelijk op mensen met een lagere sociaaleconomische status (SES). Food trucks worden veelal geassocieerd met festivals en een 'hipstercultuur', en zullen deze doelgroep mogelijk minder aanspreken.

Daarnaast is treinreizen over het algemeen strak aan tijd gebonden. De tijdsbeperking op stations leidt veelal tot gemakkelijke, welbekende routinematige gedragingen, ook in de aankoop van voedsel. Bij tijdgebrek wordt het bekende patroon gevolgd en is er weinig ruimte voor reflexief en experimenteel, ander gedrag. Bij trek onder tijdsdruk verloopt de keuze voor verkoopkanaal min of meer op de automatische piloot, 'zoals we gewend zijn te doen', wat de onderzoekers ook zelf opmerken. De mate waarin verkoopkanalen in staat zijn om kopers aan te trekken is dus niet hoofdzakelijk een kwestie van individuele keuze, maar wordt vooral gedreven door de geroutineerde, vanzelfsprekende gedragspatronen.

\section{Assortiment}

Als mogelijke verdere verklaring voor het achterblijven van de verkoop refereren de onderzoekers aan het beperkte aanbod 'dat louter uit de nieuwe taartjes bestond', wat de behoefte aan keuze zou kunnen frustreren. Dit zou het onderbrengen van de snack in het reguliere aanbod van bestaande kanalen motiveren. De assortimentsbeperking heeft echter ook nog betrekking op een ander aspect, namelijk dat van complementariteit. De onderzoekers isoleren in het experiment de productkeuze, terwijl deze onderdeel is van een bredere voedselconsumptiepraktijk. Stel, een treinreiziger heeft trek. Dan is het waarschijnlijk dat hij of zij niet alleen iets te eten, maar ook iets te drinken wil kopen. Wanneer de tijd beperkt is ligt het niet voor de hand om twee keer in de rij te gaan staan om af te rekenen. Het is dan essentieel om te begrijpen op welke wijze het 'taartje' onderdeel uitmaakt van de bredere voedselconsumptiepraktijk en hoe 'logische' combinaties gemaakt kunnen worden. Dit kan mogelijk worden ondervangen door de snack onder te brengen in een bestaand kanaal met een breder aanbod, maar wellicht ook door de taartjes te combineren met een (gratis) watertappunt. De onderzoekers hebben gevarieerd met de prijs van het product, maar mogelijk is variatie met elementen die waarde toevoegen aan de consumptiepraktijk interessanter.

\section{Product}

Het uitgangspunt van het onderzoek was de introductie van een gezond alternatief in een voedselomgeving met grotendeels ongezonde 'on-the-go-foods'. Het nieuwe 'taartje', in een zoete en een hartige variant, is gecreëerd in consultatie met de doelgroep, getest en oké bevonden. De vraag is in hoeverre de treinreizigers openstaan voor een 'nieuw', afzenderen merkloos product. Een product is meer dan een receptuur, want merken hebben ook een symbolische betekenis. In dat kader zou het bijvoorbeeld interessant kunnen zijn om te onderzoeken of er meer verkocht zou worden als op dezelfde 'nieuwe' locatie, met dezelfde 'nieuwe' food truck een 'oud', bekend ongezond product zou worden verkocht.

Daarnaast is het relevant om productontwikkeling in het bredere praktijkenperspectief te plaatsen. Wat is de betekenis van de voedselconsumptie? Gaat het om het stillen van de eerste trek tijdens het forenzen van werk naar huis, het verdrijven van tijd na een gemiste trein, of om een maaltijd die het mogelijk maakt na het werk meteen door te gaan naar het theater? Waar moet een product dan aan voldoen? Een snelle hap, een repeterende handeling of een verantwoord menu? Het product dient dus niet alleen aantrekkelijk en makkelijk verkrijgbaar te zijn, maar moet ook passen binnen de onderling verbonden praktijken van treinreizen, voedsel consumeren en andere activiteiten.

\section{Beschouwing en conclusie}

Gedragsverandering is lastig, zoals de onderzoekers opmerken. Gedragsverandering bestaat uit het doorbreken van bestaande en het creëren van nieuwe routines. Dit betekent herhaling van handelen, in dit geval gezond snacken, maar het onderzoek heeft in de onderzoeksopzet niet meegenomen of de aankopen een eenmalige ('iets nieuws') of een herhaalde ('gezonde keuze') aankoop betroffen. Hoe groter de vereiste verandering in routinematige gedragspatronen, hoe lastiger. Het experiment, gebaseerd op de causaliteit van 'aanbod schept vraag', betrof een complexe verandering met meerdere breuken in bestaande routines: een nieuw product, via een nieuw verkooppunt, 
op een nieuwe plek en daarmee op een ander moment in het treinreizen.

Om te begrijpen waarom consumenten niet overschakelden naar het gezondere alternatief is het belangrijk om meer dimensies te beschouwen dan alleen het kopen van snacks als een praktijk die losstaat van andere facetten van het dagelijks leven. De beperkte impact van interventies op veranderende gedragspatronen is toe te schrijven aan de onderlinge samenhang van praktijken. Voedselconsumptie op stations is niet alleen onlosmakelijk verbonden met de praktijk van het treinreizen, maar is een geïntegreerd onderdeel van een heel scala aan activiteiten, die gezamenlijk ons dagelijks leven vormgeven. De voedselomgeving speelt hierin een rol. Wanneer voedselconsumptie echter wordt geïsoleerd van het scala aan vaak (gecombineerde) gedragspatronen waarvan het onderdeel uitmaakt, dan is het risico dat niet alle relevante aspecten worden meegenomen in het ontwerp van een interventie.

Open Access This article is licensed under a Creative Commons Attribution 4.0 International License, which permits use, sharing, adaptation, distribution and reproduction in any medium or format, as long as you give appropriate credit to the original author(s) and the source, provide a link to the Creative Commons licence, and indicate if changes were made. The images or other third party material in this article are included in the article's Creative Commons licence, unless indicated otherwise in a credit line to the material. If material is not included in the article's Creative Commons licence and your intended use is not permitted by statutory regulation or exceeds the permitted use, you will need to obtain permission directly from the copyright holder. To view a copy of this licence, visit http://creativecommons.org/licenses/by/4.0/.

\section{Literatuur}

1. Schatzki T, Knorr Cetina K, von Savigny E, redactie. The practice turn in contemporary theory. London: Routledge; 2001.

2. Warde A. Consumption and theories of practice. J Consum Cult. 2005;5:131-53.

3. Shove E. Beyond ABC: climate change policy and theories of social change. Environ Plan A. 2010;42:1273-85.

4. Spaargaren G, Weenink D, Lamers M, redactie. Practice theory and research: exploring the dynamics of social life. Abingdon, Oxon: Routledge Taylor \& Francis Group; 2016.

5 . Linsay J. Healthy living guidelines and the disconnect with everydaylife. Crit Public Health. 2010;20:475-87.

6. Nicolini D. Practice theory work and organization: an introduction. Oxford: Oxford University Press; 2013. 